\title{
IMPLEMENTATION OF PANCASILA VALUES IN PANCASILA STUDIES COURSE ON BUILDING CHARACTER
}

\author{
TAMPILEN \\ Universitas Islam Sumatera Utara, Indonesia \\ SRI KUNARSIH \\ Universitas Islam Sumatera Utara, Indonesia \\ ZURAIDAH ADLINA \\ Universitas Islam Sumatera Utara, Indonesia
}

\section{Introduction}

Indonesians view Pancasila as a way of life that reflects the nation's personality with nationalist values. Pancasila contains values that are the cultural roots of the Indonesian nation and at the same time it is also the embodiment of the aspirations and ideals of the nation's life (Octavian, 2018). This shows that Pancasila rests on a lifestyle that is the basis for balance, harmony, and harmony in the social diversity of society. For example, there are community activities that help each other, respect and take care of each other. This activity indicates that the values of Pancasila have been embedded in social life (Octavian, 2018). 
The values contained in Pancasila are the basics that are important in social life and become guidelines for the Indonesian people to move and act with reference to the values of goodness, truth and justice (Lestari et al., 2020). Furthermore, according to Sulianti et al., (2020:64), Pancasila values can be a source of character for society, nation, education, and culture. However, over time, many external influences have made the values of Pancasila begin to fade, efforts are needed to preserve the noble values of Pancasila, namely through activities that can implement the values of Pancasila in everyday life and in the world of education (Krisnamukti et al. ., 2020).

During the COVID-19 pandemic, the existing social dynamics made people aware of the importance of instilling attitudes and behaviours such as empathy, tolerance and love for others (Sholih \& Dewi, 2021) which in principle are the noble values of Pancasila. The pandemic that has been experienced by the community has made people more tolerant and open, helping each other in alleviating the suffering of others. Public awareness of the noble values of Pancasila needs to be developed and preserved, so that these values do not appear temporarily in society. For this reason, the participation of the community and educators is needed to maintain the noble values of Pancasila in society through education.

Education plays a very important role in regenerating moral values that have been eroded. Educators must be able to be role models in behaviour so that they can motivate students to practice good values and make them personal with character, both in thinking, behaving, and acting in order to create mutual respect and respect for others (Pratama \& Dewi, 2021). Hidayat (2019) argued that there are 5 (five) appropriate strategies in building the character of students, including through activities: socialization, education, empowerment, civilizing, and cooperation.

Good learning is a learning activity that is able to shape the character of students in addition to providing an understanding of the material being taught with the intention of making students active, creative, and innovative (Lestari et al., 2020). The character of the students in question includes 18 (eighteen) attitudes (Suyadi, 2013) including: religious, honest, tolerant, disciplined, responsible, hardworking, creative, independent, democratic, curiosity, national spirit, love for the homeland, appreciate achievement, friendly / communicative, love peace, love to 
read, care about the environment and social care. Then the Regulation of the Minister of Research, Technology and Higher Education Number 44 of 2015 summarizes it into: religious, tolerant, caring, loving the homeland, respecting diversity, working together, disciplined, responsible, ethical, and independent.

\section{Method}

This case study was conducted at the Faculty of Teacher Training and Education, Islamic University of North Sumatra in the Pancasila Education course. The samples studied were taken randomly with a total sample of 30 people. The steps in this research include:

1. Carry out lectures on Pancasila Education courses,

2. Assigned students in groups to carry out social activities/social services as part of the implementation of Pancasila values,

3. Observing student activities while carrying out social activities/social services,

4. To record the character shown by students during social activities/social service,

5. Distribute Guttman scale questionnaires to students regarding their character after carrying out social activities/social services,

6. Analysed the questionnaire data and make conclusions.

The data collected is then analysed in the form of a percentage of the character of students and describes it to provide an overview of the character possessed by students after implementing Pancasila values in the Pancasila Education course.

\section{Result and discussion}

The implementation of Pancasila values is a concrete form carried out by students and lecturers. In its application, it is not only based on theory but also facts, including the attitude of respect and respect for others. In particular, the goals of Pancasila Education are contained in the goals of National Education, namely: to be a quality human being, faithful and devoted, virtuous, noble character, personality, independent, advanced 
tough, intelligent, creative, skilled, disciplined, work ethic, professional, responsible, and productive (Syamsir et al., 2017).

There are many ways to implement the principles of Pancasila, including through group work based on social activities in the academic environment, which then has a positive impact on students and the academic community (Lestari et al., 2020). Assigning students to carry out social activities/social service allows students to interpret and implement the values of Pancasila which will directly or indirectly impact on attitudes and in the end, it is hoped that it will be embedded in them as students themselves.

Questionnaires distributed to students after carrying out social activities/social service provided some information which is presented in the following table.

Table 1. Student Responses

\begin{tabular}{|c|c|c|c|c|}
\hline \multirow{2}{*}{ No. } & \multirow{2}{*}{ Attitude/Character } & \multicolumn{2}{|c|}{ Assesment } & \multirow{2}{*}{ Description } \\
\hline & & Yes & No & \\
\hline 1 & Religious & $\begin{array}{c}25 \\
(83,3 \%)\end{array}$ & $\begin{array}{c}5 \\
(16,7 \%)\end{array}$ & Good \\
\hline & $\begin{array}{ll}\text { a. } & \text { Honesty } \\
\text { b. } & \text { Truthiness } \\
\text { c. } & \text { Kindness/Worshipness }\end{array}$ & & & \\
\hline 2 & Tolerance & $\begin{array}{c}21 \\
(70 \%)\end{array}$ & $\begin{array}{c}9 \\
(30 \%)\end{array}$ & Good \\
\hline & $\begin{array}{ll}\text { a. } & \text { Composure } \\
\text { b. } & \text { Respect others } \\
\text { c. Appreciate others }\end{array}$ & & & \\
\hline 3 & Caring (social and environment) & $\begin{array}{c}17 \\
(56,7 \%)\end{array}$ & $\begin{array}{c}13 \\
(43,3 \%)\end{array}$ & Fair \\
\hline & $\begin{array}{ll}\text { a. } & \text { Helpful } \\
\text { b. } & \text { Pro-active } \\
\text { c. } & \text { Taking part }\end{array}$ & & & \\
\hline 4 & Love for homeland & $\begin{array}{c}25 \\
(83,3 \%)\end{array}$ & $\begin{array}{c}5 \\
(16,7 \%)\end{array}$ & Good \\
\hline & $\begin{array}{ll}\text { a. Loyalty } \\
\text { b. Nationalism } \\
\text { c. Spirit of unity }\end{array}$ & & & \\
\hline 5 & Value diversity & $\begin{array}{c}23 \\
(76,7 \%)\end{array}$ & $\begin{array}{c}7 \\
(23,3 \%)\end{array}$ & Good \\
\hline & a. Origin & & & \\
\hline
\end{tabular}




\begin{tabular}{|c|c|c|c|c|}
\hline & $\begin{array}{ll}\text { b. } & \text { Creative } \\
\text { c. } & \text { Critical think }\end{array}$ & & & \\
\hline \multirow[t]{2}{*}{6} & Teamwork & $\begin{array}{c}15 \\
(50 \%)\end{array}$ & $\begin{array}{c}15 \\
(50 \%)\end{array}$ & Less \\
\hline & $\begin{array}{l}\text { a. Togetherness } \\
\text { b. Focus on objective } \\
\text { c. Democratic }\end{array}$ & & & \\
\hline \multirow[t]{2}{*}{7} & Discipline & $\begin{array}{c}12 \\
(40 \%)\end{array}$ & $\begin{array}{c}18 \\
(60 \%)\end{array}$ & Less \\
\hline & $\begin{array}{l}\text { a. On-time } \\
\text { b. Obey the principle }\end{array}$ & & & \\
\hline \multirow[t]{2}{*}{8} & Responsible & $\begin{array}{c}13 \\
(43,3 \%)\end{array}$ & $\begin{array}{c}17 \\
(56,7 \%)\end{array}$ & Less \\
\hline & $\begin{array}{l}\text { a. Responsibility } \\
\text { b. Capability to take the risks } \\
\text { c. Fairness }\end{array}$ & & & \\
\hline \multirow[t]{2}{*}{9} & Ethics & $\begin{array}{c}24 \\
(80 \%)\end{array}$ & $\begin{array}{c}6 \\
(20 \%)\end{array}$ & Good \\
\hline & $\begin{array}{ll}\text { a. } & \text { Civilized } \\
\text { b. } & \text { Proper }\end{array}$ & & & \\
\hline \multirow[t]{2}{*}{10} & Independent & $\begin{array}{c}18 \\
(60 \%)\end{array}$ & $\begin{array}{c}12 \\
(40 \%)\end{array}$ & Fair \\
\hline & $\begin{array}{l}\text { a. Not dependent } \\
\text { b. Solve own problem }\end{array}$ & & & \\
\hline
\end{tabular}

Based on the data collected, it is known that several characters such as religious $(83.3 \%)$, tolerance $(70 \%)$, love for the homeland $(83.3 \%)$, respect for diversity $(76.7 \%)$ and ethics $(80 \%)$ are included in the good category. While the character of caring (56.7\%) and independence (60\%) are included in the sufficient category. The characters of cooperation (50\%), discipline (40\%), and responsibility $(43.3 \%)$ are included in the less category. This means that the character of caring and independence needs to be further developed and the character of cooperation, discipline, and responsibility needs to be instilled in students so that they become a habit and become a culture in society.

To build the character of students / students can be taken in several ways, including through the cultivation of religious activities, compassion, discipline and the culture of maintaining health and cleanliness (Wibowo et al., 2020). These four ways are seen as very effective in building the character of students, especially if they are in a school environment that is integrated with a dormitory. However, the class engineering system by creating the conditions needed for the growth of the desired character is 
also quite good, such as involving students in social activities in the wider community.

Social activities carried out by students who integrate Pancasila values in attitudes, actions, and mindsets will gradually build the character of students. Pancasila, which in this case consists of five precepts, symbolizes the five aspects of values that must be presented in the life of society and the state. The five aspects include: the divine aspect contained in the first precept, the human aspect contained in the second precept, the unity and love for the homeland contained in the third precept, the democratic aspect contained in the fourth principle and the justice aspect contained in the fifth precept. If these five aspects of Pancasila are integrated in the form of values, norms and rules that exist in people's lives, it will gradually create Indonesian people who have good national character.

The first principle in Pancasila emphasizes harmony between religious communities and as people who believe and fear God, we should put in the values of truth, kindness, honesty, and glory in ourselves (Octavian, 2018). Everything is regulated based on religious rules, so that the mindset and traditional patterns of the Indonesian people must be based on the will of God Almighty. The application of the first precepts of Pancasila can be done by respecting every difference, namely differences in diverse beliefs between communities, fostering harmony between people who have different religions and beliefs, not imposing a belief or religion on others, and fostering an attitude of mutual tolerance between religious communities. (Gultom, 2016).

The value contained in the second principle of Pancasila is the value of humanity. By implementing this second principle, students are expected to have an attitude of tolerance and a spirit of mutual respect which in the end the problems experienced by the nation such as conflicts between groups, unemployment, poverty, discrimination and social inequality and acts of violence can be resolved (Octavian, 2018). The second precept in Pancasila will also trigger students' concern for the environment and society which will regenerate mutual assistance and mutual assistance activities among the community. 
The aspect of unity contained in the third principle of Pancasila allows students to love their homeland with all their heart which can be shown in the form of loyalty, the spirit of nationalism and unity towards all policies made by the state and government.

The fourth precept in Pancasila allows students to recognize the true meaning of democracy. The democratic culture will change its perspective and mindset towards the social situation and conditions of society, as well as state politics. With democracy, students will be able to work together in completing the tasks and responsibilities assigned to them.

According to Rianto (2016: 84) the implementation of Pancasila values in the fifth precept is to make students independent, caring for each other, not only for those closest to us, but also for people we know/meet to establish harmony in the life of society and the state, maintaining the spirit of togetherness, in this case providing the much needed spirit so that humans do not feel alone.

\section{Conclusion}

Social activities carried out by students in implementing Pancasila values are an effort to build their character and show it in good attitudes, actions and mindsets. Social activities carried out by students in essence have succeeded in building their character such as religious, tolerance, love for the homeland, respect for diversity and ethics. However, other characters such as caring, independence, cooperation, discipline, and responsibility need to be developed in a culture that is integrated in their daily lives.

\section{Disclosure statement}

No potential conflict of interest was reported by the authors.

\section{Email address:}

tampilen@uisu.ac.id 


\section{References and notes:}

Gultom, A.F. (2016). Enigma Kejahatan dalam Sekam Filsafat Ketuhanan. Intizar, Vol. 22(1), 23-34.

Hidayat, S.I. (2019). Implementasi Nilai-nilai Pancasila di Perguruan Tinggi melalui Pemberian Mata Kuliah Pendidikan Bela Negara. disampaikan dalam Orasi Ilmiah pada Universitas Pembangunan Nasional Veteran Jawa Timur. Retrievedfrom:https://www.upnjatim.ac.id/images/upnjatim/documents/syarif.pdf

Johnson, A.(2021) Systemic racism in a broken special education system.International Journal of Humanities and Social Development Research. Volume 5, № 1, 2021. (7-24).Azerbaijan. http://doi.org: 10.30546/2523-4331.2021.5.1.7

Krisnamukti, B.P., Dhamayanti, K.G.H., Maharani, Y., \& Putri, S.A. (2020). Implementasi Nilai Pancasila dalam Kehidupan Mahasiswa Fakultas Pertanian Universitas Brawijaya di Malang. Jurnal Rontal Keilmuan PKn, Vol. 6(1).

Lestari, P., Sunarto, \& Cahyono, H. (2020). Implementasi Nilai-Nilai Pancasila pada Sila Kelima dalam Pembelajaran. Sosial Horizon: Jurnal Pendidikan Sosial, Vol. 7(2).

Octavian, W.A. (2018). Urgensi Memahami dan Mengimplementasikan Nilai-nilai Pancasila dalam Kehidupan Sehari-hari sebagai Sebuah Bangsa. Jurnal Bhineka Tunggal Ika, Vol. 5(2).

Peraturan Menteri Riset, Teknologi dan Pendidikan Tinggi Nomor 44 Tahun 2015 tentang Standar Nasional Pendidikan Tinggi. Jakarta: Kementerian Riset Teknologi dan Pendidikan Tinggi.

Pratama, N.Y.P., \& Dewi, D.A. (2021). Implementasi Nilai-nilai Pancasila dalam Membentuk Moral Bangsa yang Terkikis Akibat Benturan Globalisasi. Jurnal Pendidikan Tambusai, Vol. 5(1).

Rianto, H. (2016). Implementasi Nilai Kemanusiaan yang Adil dan Beradab di Lingkungan Sekolah. Sosial Horizon: Jurnal Pendidikan Sosial, Vol. 3(1).

Sholih, J.A.U., \& Dewi, D.A. (2021). Implementasi Pancasila dalam Kehidupan di Masa Pandemi Covid-19. Inventa: Jurnal Pendidikan Guru Sekolah Dasar, Vol. 5(2).

Sulianti, A., Efendi, Y., \& Sa'diyah, H. (2020). Penerapan Nilai-nilai Pancasila dalam Lembaga Pendidikan. JPK: Jurnal Pancasila dan Kewarganegaraan, Vol. 5(1).

Suyadi. (2013). Strategi Pembelajaran Pendidikan Karakter. Bandung: Remaja Rosdakarya.

Syamsir, D., Amran, A., Mashudi, \& Dharma, S. (2017). Pendidikan Pancasila Untuk Perguruan Tinggi. Palembang: Badan Kerjasama Perguruan Tinggi Negeri Wilayah Indonesia Bagian Barat (BKS PTN Barat).

Wibowo, U.B., Marini, A., Safitri, D., \& Wahyudi, A. (2020). Model of School Management Based on Character Building in School Culture. International Journal of Advanced Science and Technology, Vol. 29 (6). 


\title{
XÜLASə
}

\section{Pankasila təhsil kurslarında xarakterlərin formalaşması prosesində Pankasila dəyərlərinin tətbiqi}

\author{
Tampilen \\ Şimali Sumatra Dövlət İslam Universiteti, İndoneziya \\ Sri Kunarsih \\ Şimali Sumatra Dövlət İslam Universiteti, İndoneziya \\ Zuraidah Adlina \\ Şimali Sumatra Dövlot İslam Universiteti, İndoneziya
}

Tərbiyəçi-müəllim şagirdlərlə münasibətində, davranışlarında nümunə göstərməyi bacarmalıdır ki, şagirdlərə yaxşı dəyərləri tətbiq etməyə ruhlandırsın, başqalarına qarşı hörmət və ehtiram yaratmaqla yanaşı, həm düşüncə, davranış, həm də hərəkətlərində onları şəxsiyyətə çevirə bilsin. Buna bənzər nümunə tədqiqatı Şimali Sumatra İslam Universitetinin, Müəllim Hazırlığı və Təhsili Fakültəsində , Pancasila (İndoneziya Dövlət İdeologiyası) Təhsil kursunda aparılmışdır. Tədqiq olunan nümunələr təxmini seçilən 30 fənn arasında aparılmışdır. $\mathrm{Bu}$ tədqiqatda istifadə olunan alət, tələbələrin xarakterini müəyyən etmək üçün istifadə edilən Quttman şkalası vasitəsilə həyata keçirilən sorğu idi.

Sorğu nəticəsində məlumatlar toplandı və sonra Pankasila Təhsil kursunda Pankasila dəyərlərini tətbiq etdikdən sonra tələbələrin sahib olduğu xarakterin ümumi görüntüləri təhlil edildi.

Tədqiqatın nəticəsi onu göstərdi ki, şagirdlərin ictimai fəaliyyətləri onlarda dindarlıq, tolerantlıq, vətənə sevgi, müxtəlifliyə hörmət kimi xarakterlərin formalaşmasında mahiyyətcə uğur qazandırır. Bununla belə, şagirdlərdə qayğıkeşlik, müstəqillik, əməkdaşlıq, nizam-intizam və məsuliyyət kimi digər xarakterləri formalaşdırmaq üçün onların gündəlik həyatlarına inteqrasiya olunmuş şəkildə, bir istiqamətdə inkişaf etdirmək lazımdır.

Açar sözlor : Müallim-tərbiyaçi, xarakter, şagird, Pankasila, dayarlar, tahsil 


\title{
PEЗЮME
}

\section{Применение ценностей Панкасила в процессе формирования характера на образовательных курсах Панкасила}

\author{
Тампилен \\ Государственный исламский университет Северной Суматры, \\ Индонезия \\ Шри Кунарсих \\ Государственный исламский университет Северной Суматры, \\ Индонезия

\section{Зурайда Адлина} \\ Государственный исламский университет Северной Суматры, \\ Индонезия
}

Педагог должен уметь подавать пример в общении и поведении с учениками, вдохновлять их применять хорошие ценности, наряду с развитием уважения к другим, должен суметь превращать их в личность как в мышлении и поведении, так и в и действиях и поступках. Аналогичное тематическое исследование было проведено на образовательном курсе Панкасила (индонезийская государственная идеология) на факультете педагогической подготовки и образования Исламского университета Северной Суматры. В результате опроса были собраны данные, а затем после применения ценностей Панкасила в образовательном курсе Панкасила, были проанализированы общие образы характеров, которыми обладали студенты. Результаты исследования показали, что общественная деятельность школьников по существу успешна в формировании таких качеств, как религиозность, толерантность, любовь к родине, уважение к разнообразию. Результаты исследования показали, что общественная деятельность школьников по существу успешна в формировании таких качеств, как религиозность, толерантность, любовь к родине, уважение к разнообразию. 
Однако для того, чтобы сформировать у учащихся другие качества, такие как забота, независимость, сотрудничество, дисциплина и ответственность, им необходимо развиваться в одном направлении, интегрироваться в их повседневную жизнь.

Ключевые слова: Учитель-воспитатель, ученик, Панкасила, ценности, образование 